\title{
SPTBN1 Gene
}

National Cancer Institute

\section{Source}

National Cancer Institute. SPTBN1 Gene. NCI Thesaurus. Code C132081.

This gene plays a role in actin binding, cell shape and calcium-dependent transport. 